\title{
3 tesla magnetic resonance imaging and multiplanar reconstruction of the brain and its associated structures in sheep
}

\author{
Caner BAKICI ${ }^{1, a}$, Okan EKİM ${ }^{1, b}$, İrem ERGİN ${ }^{2, c}$, Oktay ALGIN $^{3, d}$, Çağdaş OTO ${ }^{1,4, e, \bowtie ~}$ \\ ${ }^{1}$ Ankara University, Faculty of Veterinary Medicine, Department of Anatomy; ${ }^{2}$ Ankara University, Faculty of Veterinary Medicine, \\ Department of Surgery; ${ }^{3}$ Ankara Atatürk Education and Research Hospital, Clinic of Radiology; ${ }^{4}$ Medical Design, Research and \\ Application Center-MEDITAM, Ankara, Turkey. \\ aORCID: 0000-0003-2413-3142; ' ${ }^{\mathrm{O} O R C I D: ~ 0000-0002-3322-4161 ; ~ ' ~} \mathrm{ORCID}$ : 0000-0003-2373-5133; \\ ${ }^{\mathrm{d} O R C I D: 0000-0002-3877-8366 ;}{ }^{\mathrm{e}} \mathrm{ORCID}$ : 0000-0002-2727-3768

$凶$ Corresponding author: cagdasoto @ gmail.com
Received date: 03.04.2019- Accepted date: 06.08.2019

\begin{abstract}
The purpose of the study was to scan the brain and related structures in sheep with high-resolution magnetic resonance imaging (MRI) and three-dimensional (3D) multiplanar reconstruction for defining the anatomical regions. Six adult sheep, three of six were male and three of six were female used as cadaver, were utilized in this research. Heads were scanned at 3 Tesla Siemens Magnetom Spin-Echo MRI devices using the human head coil. The processes were acquired in both T1 and T2 weighted slices and were reconstructed by using Leonardo workstation. The cranioencephalic structures and anatomical details were defined and labeled in all slice of 3 planes that were obtained $1 \mathrm{~mm}$ thickness sequential images in sagittal, frontal, and transversal planes. According to the MRI measurements obtained intracranially from the brain, the average value of length, height, and width of the brain were $87.1 \pm$ $0.3,46.8 \pm 0.7$, and $62.2 \pm 0.4 \mathrm{~mm}$, respectively. It was observed that in T1 weighted images were more effective to identify deep brain structures and anatomical details. On 3D reconstructed images obtained from the study can be used as a reference in head and brain MR scans in multidisciplinary studies where sheep are used as animal models.
\end{abstract}

Keywords: Animal model, MRI, nervous system, sheep, 3D reconstruction.

\section{Koyunda beyin ve ilişkili yapıların 3 tesla manyetik rezonans ile görüntülenmesi ve multiplanar rekonstruksiyonu}

Özet: $\mathrm{Bu}$ çalışmada, koyun beyni ve beyin çevresindeki anatomik yapıların, yüksek çözünürlüklü manyetik rezonans ile görüntülenmesi ve 3 boyutlu (3B) multiplanar rekonstruksiyonu ile bölge anatomisinin özelliklerinin belirlenmesi amaçlandı. Araştırma için 3 erkek, 3 dişi toplam 6 yetişkin koyun kullanıldı. Tüm kafalar 3 Tesla Siemens Magnetom Spin-echo manyetik rezonans görüntüleme cihazı ile insan kafa koili kullanılarak tarandı. Tarama işlemi hem T1, hem de T2-ağırlıklı olarak yapıldı ve Leonardo workstation kullanılarak rekonstrüksiyonu yapıldı. Sagittal, frontal ve transversal düzlemlerde alınan yaklaşık 1 mm kalınlığındaki ardışık kesit görüntülerinin üzerinde kafa yapıları ve anatomik detaylar üç düzlemde ve her kesit üzerinde tanımlanarak işaretlendi. Kesit görüntüleri üzerinden yapılan kafa içi ölçümlerde encephalon’un ortalama uzunluğu, yüksekliği ve genişliği sırasıyla $87.1 \pm 0.3$, $46.8 \pm 0.7$ ve $62.2 \pm 0.4 \mathrm{~mm}$ olarak ölçüldü. T1 ağılıklı görüntülerin, derin beyin yapılarının ve anatomik detayların tanımlanmasında daha etkili olduğu görülmüştür. Hayvan modeli olarak koyunun kullanıldığı multidisipliner çalışmalarda, 3B rekonstrüksiyon ile elde edilen görüntülerin, baş ve beyin MR taramalarında referans olarak kullanılabilir.

Anahtar sözcükler: Hayvan modeli, koyun, MRG, sinir sistemi, 3B rekonstrüksiyon.

\section{Introduction}

The advantages of using magnetic resonance imaging (MRI) are being the noninvasive clinical approach, a keen diagnostic tool $(9,13,14,24)$ and acquiring comprehensive information about neuroscience (4-6). Improvements in MRI techniques can make the determination of pathologies or injuries on the brain and spinal cord easily $(2,9,11)$. It also finds a use for diagnosing zoonoses such as hepatica fascioliasis or cerebral coenurosis $(10,17)$. In addition to these MRI is accepted as a gold standard method for examination of muscle morphometric parameters such as cross-section areas and muscle fatty infiltrates (25).

An ovine model can be used because of having anatomical and physiological similarities to the human body than other experimental species, such as the size of fetal sheep pregnancy and imaging features $(6,18)$. This animal model has become important for surgical and 
anatomical cerebral studies because of its size $(6,14,27)$, biomedical imaging and implant testing studies (21), biomechanics of the spine disorders $(13,28)$, diagnosing of diseases on prematurity $(22,24)$, monitoring the effectiveness of treatment on diseases such as epilepsy or neurologic decompression sickness $(11,23)$. The shape of the sheep skull shows similarity like humans, so this can be useful for studies (16). Sheep is also become an alternative animal model due to a physiological examination of genes for reproductive functions $(1,7)$ and endocrine regulations related to reproductive physiology (5).

The aim of this study was to define imaging features of the normal anatomical structures of the brain and round tissues in the sheep MR images. By this way, it helps the clinicians to compare the head pathologies with normal anatomy and as a reference to the biomedical investigations for researchers.

\section{Material and Methods}

This study was carried out with the 2013/18 numbered permission of the Bilkent University Animal Experiments Ethics Committee. In this study, 3 male and 3 female total 6 adult Akkaraman sheep fresh cadavers obtained from the faculty farm were used. The weights of the sheep were $40 \pm 3 \mathrm{~kg}$. The heads of the sheep were placed in "prone" position and were scanned using a 3Tesla Siemens Magnetom Spin-echo magnetic resonance imaging device (Siemens Magnetom Trio, Erlangen, Germany) with an 8-channel human head coil and a 15channel human knee coil. Whole brain and associated structures were scanned with three-dimensional (3D), T1weighted (W) gradient echo inversion recovery (IR) multiplanar reconstruction (MPR) sequence in the sagittal plane with isotropic voxels for reformation and $3 \mathrm{D}$ reconstructed by Leonardo Workstation software (Siemens Medical Solutions, Erlangen, Germany). Parameters for T1-weighted images during scans; TE: 12 ms; TR: $600 \mathrm{~ms}$; Section Thickness: $1 \mathrm{~mm}$; FOV: $230 \times$
$230 \mathrm{~mm}$; Number of sections: 125; Scanning time; 8 minutes, parameters for T2-weighted images; TE: $404 \mathrm{~ms}$; TR: 3000 ms; Section Thickness: $1 \mathrm{~mm}$; FOV: $230 \times 230$ mm; Number of sections: 125; Scanning time; 11 minutes. Nomina Anatomica Veterinaria was used for the nomenclature (12). Identification of the anatomical structures were based on the textbooks $(3,15)$.

\section{Results}

All animals successfully underwent MRI progress. In MR images, anatomical structures of the brain did not contain any differences in shape or signal intensities described. T1 and T2 weighted MR images were performed in detail for whole brain and associated structures in three planes that were acquired $1 \mathrm{~mm}$ thickness consecutive images in sagittal, frontal and transversal planes. Morphological features of the MR images were illustrated in Figure 1, 2, and 3. According to the measurements of the brain obtained intracranially with MRI, the average values of length, height, and width of the brain were $87.1 \pm 0.3 \mathrm{~mm}, 46.8 \pm 0.7 \mathrm{~mm}$ and $62.2 \pm$ $0.4 \mathrm{~mm}$, respectively.

After the colored reformation of images in $\mathrm{T} 1$ weighted series scanned with 3D-IR-MPR sequence, the anatomic details were clearly defined, and the grey and white matters were also recognized more easily from each other (Figure 1A, 1B, and 1C). It has been observed that anatomical details and deep brain structures can be easily detected on T1 weighted images. The grey matter was more hypointense when compared with the white matter (Figure 1D, 2B, and 3D). The brain tissue could be easily separated from other surrounding tissues (head bones, muscles, fat tissues) because of the high tissue contrast provided by the MR images (Figure 1C, 2C, 3B, and 3C). In the image scans, the bones were monitored isointense (Figure 1C), muscles were hypointense appearance (Figure 1D), and fat tissues were identified hyperintense (Figure 3B).

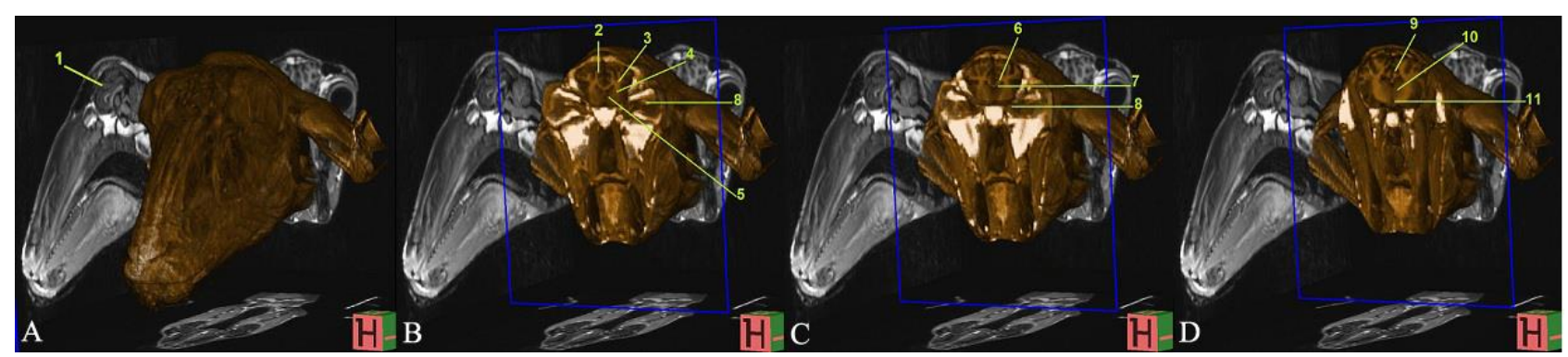

Figure 1. The transversal 3D-IR-MPR images of the head (A. Three dimensional view of the sheep head, B. At the level of caudate nuclei, C. At the level of lateral ventricle and D. At the level of middle of thalamus). 1. Sagittal T1 weighted image, 2. Cerebral cortex, 3. Semioval center, 4. Internal capsule, 5. Caudate nucleus, 6. Corpus callosum, 7. Lateral ventricle, 8. Optic chiasma, 9. Cingulum, 10. Thalamus, 11 . Third ventricle. 


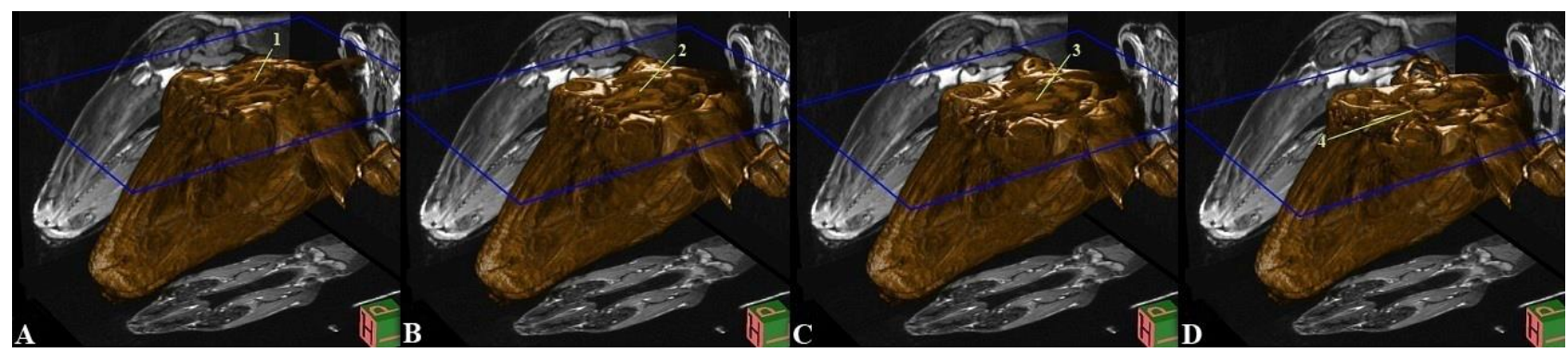

Figure 2. The frontal 3D-IR-MPR images of the head (A. At the level of lateral ventricle, B. At the level of rostral colliculi, C. At the level of middle of thalamus and D. At the level of optic chiasm). 1. Lateral ventricle, 2. Thalamus, 3. Cerebral aqueduct, 4. Optic chiasm.

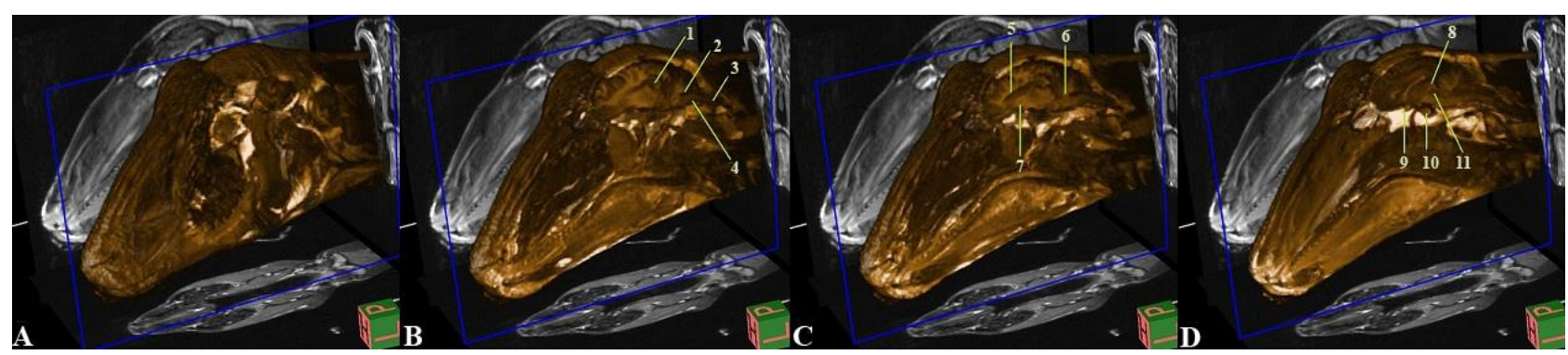

Figure 3. The sagittal 3D-IR-MPR images of the head (A. At the level of beginning of left cerebral hemisphere, B. At the level of left hippocampus, C. At the level of left lateral ventricle and D. At the level of middle of brain). 1. Hippocampus, 2. Fourth ventricle, 3 . Spinal cord, 4. Medulla oblongata, 5. Lateral ventricle, 6. Middle cerebellar peduncles, 7. Internal capsule, 8. Rostral colliculus, 9. Optic chiasma, 10. Pituitary gland, 11. Cerebral aqueduct.

In addition to these, the anatomical details of deep cerebral structures such as cortex cerebri, capsula interna, nucleus caudatus, corpus callosum, ventriculus lateralis, chiasma opticum, thalamus and ventriculus tertius on transversal sections were identified from 3D images (Figure 1A-D). Ventriculus lateralis and aqueductus mesencephali were also observed in coronal sections (Figure 2A-D). Hipophysis, aqueductus mesencephali, colliculus rostralis, hypocampus, pedunculus cerebellaris medius, medulla oblongata, ventriculus quartus, and medulla spinalis were identified on a sagittal section of 3D images (Figure 3 A-D). Orbita and its surrounding tissues on coronal sections (Figure 2D), mandibula, pharynx, skull bones, meninges and muscles on transversal sections (Figure 1C and 1D) and cavum nasi, lingua, and palatum on sagittal sections (Figure 3D) were also seen as well.

\section{Discussion and Conclusion}

The present study demonstrated the applicability of the 3D-IR-MPR imaging for brain and its surrounding tissues in a healthy sheep model. The use of sheep as an anatomical model is developing. Many studies made in recent years have strengthened this consideration due to the sheep brain and its anatomical characteristics $(5,6$, 16).

In previous studies, it has been stated that MR images are used in the diagnosis process of diseases $(8$,
29). It has also been suggested that MR studies on specimens to see the similarities or differences for normal anatomical structures, were important for other researchers such as surgeons, radiologists $(4,16,19,20$, 26). It was thought that the images obtained from this study can be used as a teaching material in anatomy education, as well as the normal structure, size, position, etc. on these $3 \mathrm{D}$ images can be compared with the pathological features that may occur in the brain, brain membranes or cerebrospinal fluid. In addition to the $3 \mathrm{D}$ images from this study, this colored 3D reconstructed images to transmit and visualize the interaction of the brain with surrounding tissues better compared with $\mathrm{T} 1$ weighted and T2 weighted images.

As a result, MRI has become one of the routine imaging techniques in many veterinary fields. It is considered that reconstructed three-dimensional images obtained from MR images can be used as an important source not only the recognition of pathological tissues and during the preparation phase of operation in the clinic but also in veterinary anatomy training for understanding the morphology of the structures more easily.

\section{Conflict of Interest}

The authors declared that there is no conflict of interest. 


\section{References}

1. Avanus K, Altınel A (2016): Identification of genetic variation of melatonin receptor 1 a (mtnrla) gene in klvirclk breed ewes by mnli and rsai restriction enzymes. Kafkas Univ Vet Fak Derg, 22, 571-576.

2. Brachthäuser L, Klumpp S, Hecht W, et al (2012): Aprosencephaly with otocephaly in a lamb (Ovis aries). Vet Pathol, 49, 1043-1048.

3. DeLahunta A, Glass E, Kent M (2009): Veterinary Neuroanatomy and Clinical Neurology. W. B. Saunders Company. St Louis.

4. Ekim O, Oto C, Algın O, et al (2013): High resolution 3D magnetic resonance imaging of the visceral organs in chicken (Gallus domesticus) by 3 Tesla MR unit and 15channel transmit coil. Ankara Univ Vet Fak Derg, 60, 229233.

5. Ella A, Delgadillo JA, Chemineau P, et al (2017): Computation of a high-resolution MRI $3 D$ stereotaxic atlas of the sheep brain. J Comp Neurol, 525, 676-692.

6. Ella A, Keller M (2015): Construction of an MRI 3D high resolution sheep brain template. Magn Reson Imaging, 33, 1329-1337.

7. Elmacı C, Şahin Ş, Öner, Y (2013): Distribution of different alleles of aromatase cytochrome P450 (CYP19) and melatonin receptor $1 A$ (MTRN1A) genes among native Turkish sheep breeds. Kafkas Univ Vet Fak Derg, 19, 929933.

8. Ertelt K, Oevermann A, Precht C, et al (2016): Magnetic resonance imaging findings in small ruminants with brain disease. Vet Radiol Ultrasound, 57, 162-169.

9. Evangelisti MA, Varcasia A, Deiana R, et al (2016): Clinical evolution of cerebral coenurosis from invasive to chronic infection in sheep and a goat. J Infect Dev Ctries, 10, 1151-1155.

10. Gonzalo-Orden M, Millán L, Alvarez M, et al (2003): Diagnostic imaging in sheep hepatic fascioliasis: ultrasound, computer tomography and magnetic resonance findings. Parasitol Res. 90, 359-364.

11. Hutchinson EB, Sobakin AS, Meyerand ME, et al (2013): Diffusion tensor MRI of spinal decompression sickness. Undersea Hyperb Med, 40, 23-31.

12. International Committee on Veterinary Gross Anatomical Nomenclature (2017): Nomina Anatomica Veterinaria (N.A.V.). 6th ed., World Association of Veterinary Anatomists, Hannover, Gent, Columbia, Rio de Janeiro.

13. Jazini E, Sharan AD, Morse LJ, et al (2012): Alterations in $T 2$ relaxation magnetic resonance imaging of the ovine intervertebral disc due to nonenzymatic glycation. Spine, 37, 209-215.

14. Koff MF, Shah P, Pownder S, et al (2013): Correlation of meniscal T2* with multiphoton microscopy and change of articular cartilage T2 in an ovine model of meniscal repair. Osteoarthritis Cartilage, 21, 1083-1091.
15. König HE, Liebich HG, Cerveny C (2004): Veterinary Anatomy of the Domestic Mammals. Part 14. 465-536. In: HE König and HG Liebich (Ed), Nervous System. Schattauer, Stuttgart.

16. Lee W, Lee SD, Park MY, et al (2015): Functional and diffusion tensor magnetic resonance imaging of the sheep brain. BMC Vet Res, 11, 262-270.

17. Manunta ML, Evangelisti MA, Burrai GP, et al (2012): Magnetic resonance imaging of the brain and skull of sheep with cerebral coenurosis. Am J Vet Res, 73, 1913-1918.

18. Much CC, Schoennagel BP, Yamamura J, et al (2013): Diffusion-weighted MR imaging of fetal lung maturation in sheep: effect of prenatal cortisone administration on ADC values. Eur Radiol, 23, 1766-1772.

19. Nisolle JF, Wang XQ, Squélart M, et al (2014): Magnetic resonance imaging (MRI) anatomy of the ovine lumbar spine. Anat Histol Embryol, 43, 203-209.

20. Oto C (2017): Köpekte beynin 3 tesla manyetik rezonans ile 3 boyutlu multiplanar rekonstruksiyonu. Harran Üniv Vet Fak Derg, 6, 69-72.

21. Silemek B, Acikel V, Oto C, et al (2018): A temperature sensor implant for active implantable medical devices for in vivo subacute heating tests under MRI. Magn Reson Med, 79, 2824-2832.

22. Skiöld B, Wu Q, Hooper SB, et al (2014): Early detection of ventilation-induced brain injury using magnetic resonance spectroscopy and diffusion tensor imaging: an in vivo study in preterm lambs. PLoS One. 9, e95804.

23. Stypulkowski PH, Stanslaski SR, Jensen RM, et al (2014): Brain stimulation for epilepsy-local and remote modulation of network excitability. Brain Stimul, 7, 350358.

24. Tkach JA, Hillman NH, Jobe AH, et al (2012): An MRI system for imaging neonates in the NICU: initial feasibility study. Pediatr Radiol, 42, 1347-1356.

25. Valentin S, Licka TF, Elliott J (2015): MRI-determined lumbar muscle morphometry in man and sheep: potential biomechanical implications for ovine model to human spine translation. J Anat, 227, 506-513.

26. Vandeweerd JM, Kirschvink N, Muylkens B, et al (2013): Magnetic resonance imaging (MRI) anatomy of the ovine stifle. Vet Surg, 42, 551-558.

27. Wells AJ, Vink R, Blumbergs PC, et al (2012): A surgical model of permanent and transient middle cerebral artery stroke in the sheep. PLoS One, 7, e42157.

28. Wijayathunga VN, Ridgway JP, Ingham E, et al (2015): Nondestructive method to distinguish the internal constituent architecture of the intervertebral discs using 9.4 tesla magnetic resonance imaging. Spine, 40, 1315-1322.

29. Zaky MR, Shaat RM, El-Bassiony SR, et al (2015): Magnetic resonance imaging (MRI) brain abnormalities of neuropsychiatric systemic lupus erythematosus patients in Mansoura city: Relation to disease activity. Egypt Rheumatol, 37, 7-11. 